\title{
ORIGINS OF INDONESIA AND THE SUSTENANCE OF ITS EXCELLENCE, 1966-2015
}

\section{Benedict R. O'G. Anderson}

In the history of journals that are not controlled by states, big businesses, or very large and wealthy private institutions, most are born from the end of huge wars, political crises, nostalgia, exciting new ideas, migrations, passions, or controversies. Many of them are like comets-brilliant for a short time and then disappear due to financial problems, shrinking audiences, global disasters, exhaustion, fads, or absorption into bigger journals. The questions, then, are why did Indonesia come into existence in 1966, and how has it been sustained for fifty years, such that we are now celebrating this one-hundredth issue.

A. Toward the end of the nineteenth century American universities organized themselves on "scientific" departmental lines, and created "nationwide" journals to fit. For example: the American Review, in 1895; the American Economic Review, in 1911; and the American Political Science Review, in 1906. But in the Netherlands East Indies (NEI), as in neighboring British and French colonies, journals were created in the same period by the state. The contributors were usually intelligent bureaucrats and specialists who lived there for lengthy periods, learned local languages, and worked with various native elites. A good example was Djawa, in which you might find articles on Javanese music, economics, religion, urban engineering, archaeology, traditions, governance, and so on. In the United States, those researching Indonesia after WWII were mainly

Benedict R. $O^{\prime} G$. Anderson is the Aaron L. Binenkorb Professor Emeritus of International Studies, Government, and Asian Studies at Cornell University. 
professors and students in private universities, whose teaching and classroom responsibilities made it rare that they could stay long enough in Indonesia to master local languages, in addition to Dutch.

In the 1950s, the United States was working to be the hegemon of Southeast Asia as the region's colonies became independent. Washington created the concept of "South East Asia," but it was ignorant of this vast zone, and the number of SEA scholars in universities was very small. Then came the founding of Yale's and Cornell's Southeast Asia Programs (SEAP) from 1948 to 1950, structured in hegemon style. Class titles usually started with "Southeast Asia," not single countries, not even Indonesia. When students went to do research in a huge country where few citizens could speak English, they had to learn Indonesian, as well as Dutch, to read the colonial journals. These were nothing like US disciplinary journals. Beyond this, young students studying Indonesia's history, religions, traditions, music, politics, etc. fairly soon felt a strong emotional attachment to this new nation, something very rare in disciplinary American reviews. When I returned to Cornell in August 1964, after two and a half years in Java and a summer in Amsterdam, I had the idea that there should be a journal for Indonesia on the prewar colonial pattern, but with enthusiasm for the nation itself. In the summer of 1965, Ruth McVey, Fred Bunnell, and I discussed the idea that we should try to do it at Cornell, because Cornell had bought the best library on Indonesia, the best teachers of the Indonesian language, and the best group of professors studying the country. After that we went to our great mentor, George Kahin, who cheered us on, and promised some financial support. Was that all? No.

B. The 1960s. In August 1964, US President Johnson faked a Vietnamese attack against the American navy in the Tonkin Gulf. With this excuse, a colossal and brutal war started against small Vietnam. Huge numbers of students and other youngsters were conscripted (the last time the United States dared to use the conscription laws). Students, especially, rebelled with furious demonstrations, long marches, leftist activity, campus strikes, and political bulletins. George Kahin was among the first to denounce the war on national television. His Cornell lectures on the follies of American foreign policy brought in hundreds of students. It was indicative of the atmosphere that when Cornell's SEAP and anthropology departments together wanted to hire a new young professor, the graduate students demanded that they be allowed to vote and the faculty more or less gave in. The faculty's top candidate was rejected and Jim Siegel was hired instead. He wrote the first article in Indonesia, as you will see.

C. It is still strange that we got the journal going quite so soon. There were only three of us as editors, and none had publishing experience. Fred and I were still graduate students, far from finishing our PhDs. Ruth had published in 1962 her great book on early communism in Indonesia. George found a very fine typist for us. It is interesting what our first issue contained: (a) James Siegel, "Prayer and Play in Atjeh: A Comment on Two Photographs"; (b) Ernst Heins (Dutch musicologist, whom I got to know while in Amsterdam), "Supplemental Note on a Recent Javanese Gamelan Record"; (c) Lance Castles (Australian; Yale historian), "Notes on the Islamic School at Gontor"; (d) Semaun's "An Early Account of the Independence Movement," translated by Ruth McVey; (e) Judith Hudson (anthropology), "Letters from Kalimantan"; (f) Ben Anderson, "The Languages of Indonesian Politics"; (g) two stories of Idrus translated by a Cornellian, Mrs. S. U. Nababan; (h) John M. Echols (Cornell professor), "Notes on 
Materials for the Study of Atjeh;" and (i) seven "Selected Documents Relating to the September 30th Movement and Its Epilogue," compiled by the editors.

One should highlight two valuable types of notes during the first six issues of Indonesia. First, there are those like John Echols's "In Memoriam" of the great Dutch bibliographer G. F. Oekeloen (1966); Harry Benda's touching account of the death of the great French scholar of Indonesia Louis Charles Damais (1967) (Benda was effective leader of Yale's SEAP); and Claire Holt's obituary for Robert Heine-Geldern, the famous Austrian anthropologist and historian of ancient South East Asia. In those years, the scholarly linkage with Europeans was still strong, although eventually it faded away. Second, in the fourth issue, one can see Joel E. Rocamora's "Recent Changes in Army Commands," about Indonesia's military. Fed up with his own Filipino oligarchs and admiring Soekarno, he learned Indonesian excellently while doing fieldwork there, and later did a fine PhD at Cornell's SEAP on Indonesia's Nationalist Party. He was happy to help Indonesia by starting what became the journal's plan to continue detailed research on the military, a task which has lasted into the twenty-first century.

D. Disasters. About two or three months after we agreed on building Indonesia came the murky September 30th Movement (Gerakan 30 September, G30S), which resulted in several top generals being killed. The movement immediately failed, and General Suharto took power and arranged the murders of about two million communists and sympathizers. The three of us immediately tried to solve the G30S mystery on the basis of all the documents we could discover. In the first week of January we finished what we quietly called a "Preliminary Analysis of the October 1, 1965, Coup in Indonesia," agreeing that most likely the "coup" was made by soldiers and not by communists. Fearing that innocent Indonesian friends might suffer, we kept the text secret except for about six really reliable comrades. But in February 1966 the Washington Post released parts of it, and, of course, it enraged Suharto as well as American bureaucrats in the capital. We swore not to give up the journal. So in the first issue we included seven important documents on G30S. In 1972 I was expelled from Indonesia for twenty-seven years, but Indonesia was never dissolved.

E. Changes. When I presented my PhD in 1967, some of the examining professors in the government department cheerfully asked, "Is this political science or history"? Yet when I became a junior professor, I didn't enter the History Department. But as time passed, the walls between the social sciences and humanities became higher, and even in a single department smaller walls appeared. Here is a nice example. When I was a senior professor, the dean asked me and a nice mathematics colleague to find out why, for over ten years, there had not been a single new junior professor hired in the psychology department. I found out that the department was split into three equal-size groups, each of which had no understanding and respect for the others. If one group put up their candidate, the other two immediately blocked the move. In the late-1980s, I noticed that most departments had been developing disciplinary argots-tiresome, ugly, and difficult to be understood by members of other departments as well as by the general public. Moreover, what has been getting worse is the creeping commercialism of universities over the last twenty years, a condition in which many professors are forced to "bring in money" for their inner bureaucratic institutions. Finally, graduate students seem to be more timid than in earlier generations. In Indonesia, will their 
research produce fine books on the military, the culture of upper-middle-class Chinese billionaires, literature that is or was banned, a history of Indonesian communism under Aidit, the ten most ugly buildings in Jakarta and who built them, etc.?

F. Let me end with something excellent that has transformed Indonesia. After Fred Bunnell went to teach in Poughkeepsie, New York, and Ruth McVey in London, I struggled along with the help of many energetic graduate students and their spouses for short periods. But eventually Audrey Kahin took full command of the journal, from 1978-95. She had learned how to be a professional editor while still in England, got a PhD in Indonesian history at Cornell, and, together with George Kahin, had a lot of experience in many parts of Indonesia. It did not take her long to turn our little Indonesia into a truly professional journal. Her successor, Deborah Homsher, who was managing editor from 1995-2014, is a writer and a fine professional editor, who, along with her husband, had the courage to go to Jogjakarta for some months to learn a lot about Indonesia. Her elegant prose was excellent armor against the ugly prose of many academics' submissions. I think she jokingly called me "Bad Cop," because of the ruthless way I criticized the work of some colleagues and students, and I called her "Good Cop" for the graceful and helpful letters she sent to the same persons. The work of Audrey and Deborah has certainly made Indonesia an A+ international journal, and we are now glad to have Sarah Grossman as the third professional editor of Indonesia. 